\title{
Factors influencing the occurrence of negative interactions between people and crocodilians in Mexico
}

\author{
Giovany Arturo González-Desales, Luis Sigler, Jesús García-Grajales \\ Pierre Charruau, Martha Mariela Zarco-González \\ Ángel BALBUENA-SERRANO and OCTAVIO MONROY-VILChis
}

\begin{abstract}
Negative interactions between people and crocodilians have increased worldwide, but in Mexico there have been few systematic reports and no rigorous evaluation of this problem. We compiled information on negative interactions between people and the spectacled caiman Caiman crocodilus and American crocodile Crocodylus acutus from the Worldwide Crocodilian Attack Database for 1993-2018, and we investigated interactions in greater depth, through interviews with people in La Encrucijada Biosphere Reserve. We examined the relationship between the occurrence of negative interactions between people and $C$. acutus and the species' nesting season and abundance, and presence records. In Mexico, the frequency of negative interactions increases when anthropogenic activities occur close to nesting sites $(<30 \mathrm{~km})$ and during the nesting season (February-September). In La Encrucijada, following negative interactions with crocodiles, the local inhabitants killed 30 crocodiles measuring $>2.5 \mathrm{~m}$ long in 2011-2012. The frequency of negative human-crocodilian interactions was not correlated with the abundance of crocodilians but was correlated with the number of presence records of crocodiles. Strategies to minimize these interactions include warnings at nesting sites, increased monitoring of anthropogenic activities during the nesting season, and management of nests to prevent them being destroyed by people.
\end{abstract}

Keywords Caiman crocodilus, crocodile, Crocodylus acutus, human activities, human-crocodile conflict, Mexico, nesting, relative abundance

\footnotetext{
Giovany Arturo GonZález-Desales, Martha Mariela Zarco-González, Ángel Balbuena-Serrano and Octavio Monroy-Vilchis (Corresponding author) Centro de Investigación en Ciencias Biológicas Aplicadas, Universidad Autónoma del Estado de México, Instituto Literario 100, Col. Centro, C.P. 50000 Toluca, Estado de México, Mexico

E-mail tavomonroyvilchis@gmail.com

Luis SigLer The Dallas World Aquarium, Dallas, USA

Jesús García-Grajales Universidad del Mar Campus Puerto Escondido, San Pedro Mixtepec, Oaxaca, Mexico

Pierre Charruau Centro del Cambio Global y la Sustentabilidad A.C. Calle Centenario del Instituto Juárez s/n, Villahermosa, Tabasco, Mexico

Received 7 August 2018. Revision requested 30 October 2018.

Accepted 4 June 2019. First published online 21 May 2021.
}

\section{Introduction}

$\mathrm{O}$ $f$ the 24 species of crocodilians (Uetz et al., 2016), one species of the family Alligatoridae, the spectacled caiman Caiman crocodilus, and two species of the family Crocodylidae, the American crocodile Crocodylus acutus and Morelet's crocodile Crocodylus moreletii occur in Mexico. On the IUCN Red List C. crocodilus and C. moreletii are categorized as Least Concern and C. acutus as Vulnerable (Cedeño-Vázquez et al., 2012; Ponce-Campos et al., 2012; Balaguera-Reina \& Velasco, 2019), and in Mexico the three species are subject to Special Protection (SEMARNAT, 2010). Populations of $C$. acutus and C. crocodilus were severely affected by hunting for their skins until this was permanently banned in the 1970s. Since then the populations of the three species have increased, although in some regions of Mexico they are still exploited (INE-SEMARNAP, 1999; Aguilar-Galindo, 2005).

As a result of this recovery of crocodilian populations, and because of land-use change, flooding, human population growth and feeding of crocodiles by people, negative interactions between people and crocodiles have escalated (García-Grajales, 2013). Crocodile behaviour, such as territorial and self defence, and nest protection by females, exacerbate these negative interactions (Pooley et al., 1989; García-Grajales \& Buenrostro-Silva, 2018). In the Americas, C. acutus and C. moreletii have been involved in a number of fatal incidents, with 2.9 and 0.5 cases/year, respectively (Sideleau, 2015). Such incidents are not, however, always recorded (Aust et al., 2009). Systematic compilation of data on interactions between people and crocodilians is required to identify the potential risks to people from crocodiles, and to avoid retaliatory killings (Caldicott et al., 2005).

In the state of Chiapas in Mexico negative interactions between crocodiles and people could be expected, as all three species occur there, but in the Worldwide Crocodilian Attack Database (CrocBITE, 2018) only four incidents have been recorded in this state, which is probably an underestimate. Here we examine the following questions: (1) Does the frequency of negative human-crocodilian interactions increase during the nesting season? (2) Does the frequency of incidents increase when there is human habitation within nesting areas? (3) Does the frequency of such interactions increase with crocodile abundance, both nationally in 
TABLE 1 Records of the relative abundance index of Crocodylus acutus in Mexico during 1987-2012, from various sources, and in 2014.

\begin{tabular}{llrl}
\hline & \multicolumn{3}{c}{$\begin{array}{l}\text { Relative } \\
\text { abundance }\end{array}$} \\
Locality, State & Year & index & Source \\
\hline Amela lagoon, Colima & (not indicated) & 45 & Castillo (1996) \\
Chamela-Cuixmala Biosphere Reserve, Jalisco & $1987-2003$ & 20.57 & García et al. (2010) \\
Chiricahueto lagoon, Sinaloa & 1996 & 6.94 & León-Ojeda et al. (1997) \\
La Encrucijada, Biosphere Reserve, Chiapas & 1996 & $2.1(11.5)$ & Martínez-Ibarra et al. (1997) \\
El Verde estuary, Sinaloa & $1999-2000$ & 7.7 & Navarro-Serment (2001) \\
Boca Negra estuary, Jalisco & $1999-2002$ & $45.4(0.7)$ & Huerta (2005) \\
La Manzanilla estuary, Jalisco & $1999-2002$ & $40.9(2.3)$ & Huerta (2005) \\
La Ventanilla estuary, Oaxaca & $2000-2001$ & $47.3(9.7)$ & Espinosa-Reyes \& García-Grajales (2001) \\
Majahuas estuary, Jalisco & $2000-2002$ & $5.2(4.6)$ & Huerta (2005) \\
Boca Negra estuary, Jalisco & 2001 & $18.25(0.8)$ & Cupul-Magaña et al. (2002) \\
Sumidero Canyon National Park, Chiapas & 2001 & $2.8(15)$ & Sigler (2010) \\
Banco Chinchorro Biosphere Reserve, Quintana Roo & 2003 & 6.8 & Charruau et al. (2005) \\
La Palmita lagoon, Oaxaca & $2004-2005$ & $6.38(4.9)$ & Brandon-Pliego (2007) \\
San Blas estuary, Nayarit & $2005-2007$ & $1.94(14.8)$ & Hernández-Hurtado et al. (2011) \\
El Cajon reservoir, Nayarit & $2010-2011$ & $0.67(15.2)$ & González (2013) \\
Majahuas estuary, Jalisco & $2010-2015$ & 10.46 & Tello (2016) \\
San Juan lagoon, Jalisco & $2010-2015$ & 8.75 & Tello (2016) \\
Palmasola lagoon, Oaxaca & 2012 & $70.1(0.6)$ & García-Grajales \& Buenrostro-Silva (2014) \\
La Encrucijada, Biosphere Reserve, Chiapas & 2014 & $1.5(28)$ & This study \\
\hline
\end{tabular}

${ }^{1}$ Surveyed km, where known, are given in parentheses.

Mexico and locally in El Hueyate estuary in Chiapas? In addition, we examine the relationship of the number of negative incidents and presence records of $C$. acutus with socio-economic variables.

\section{Methods}

\section{Negative interactions with C. acutus in Mexico}

Monthly records of negative interactions with C. acutus in Mexico, with geographical coordinates, were compiled from CrocBITE (2018) for 15 August 1993-8 June 2018. From the coordinates we calculated the Euclidean distances to the nearest nesting site (Casas-Andreu, 2003; Cedillo-Leal et al., 2013; Cupul-Magaña et al., 2004; Valtierra-Azotla, 2007; Charruau et al., 2010; Sigler, 2010; Charruau et al., 2011; Hernández-Hurtado et al., 2011; González-Desales et al., 2016a; Charruau et al., 2017) and to the nearest site for which relative abundance data were available (Table 1), using ArcGis 10.2 (Esri, Redlands, USA). The distance of interactions to nesting sites and the distance of interactions to sites where abundance of $C$. acutus had been evaluated were classified in intervals, based on the Rule of Sturges (Sturges, 1926). Using simple linear regression, we examined the relationships between interaction frequency and proximity to nesting sites, relative abundance of crocodiles, and number of presence records of $C$. acutus up to 18 June 2018, (the latter from GBIF, 2017). A $\chi^{2}$ test was used to identify any association between interactions and the nesting season of C. acutus. We describe six socio-economic characteristics of Mexican municipalities (INEGI, 2019) with records of negative interactions and the presence of crocodiles: (1) principal economic activity (as primary: agriculture, livestock, forestry, hunting, fishing; secondary: mining, oil and gas extraction, manufacturing, electricity, water supply, construction; services: transport, government, other), (2) education level of males (mean years of study), (3) human population density (inhabitants $/ \mathrm{km}^{2}$ ), (4) number of males in the population, (5) number of economically active males, and (6) municipality area (ha). We focused only on the characteristics of the male population, as negative interactions occur most frequently with them (García-Grajales \& Buenrostro-Silva, 2019).

\section{Human-crocodilian interactions in El Hueyate estuary}

El Hueyate estuary in the La Encrucijada Biosphere Reserve on the Pacific coast of Chiapas state (Fig. 1) has two core areas (36,216 ha: El Palmarcito and La Encrucijada), and a 108,651 ha buffer zone (INE-SEMARNAP, 1999). Within the Reserve the caiman subspecies $C$. crocodilus chiapasius and $C$. acutus occur in both natural and anthropogenic ecosystems (dams, cattle ponds, fishery ponds and pampas; Sigler, 1996). There are 64 human settlements and 26,992 inhabitants in the Reserve, of which $28.5 \%$ do not receive school education of any level; the main economic activities are fishing, agriculture and livestock breeding (INESEMARNAP, 1999). Reports indicate there are more crocodilians in the core zone than elsewhere (Sigler \& Martínez-Ibarra, 1998; Peña, 2011) and nesting of both 


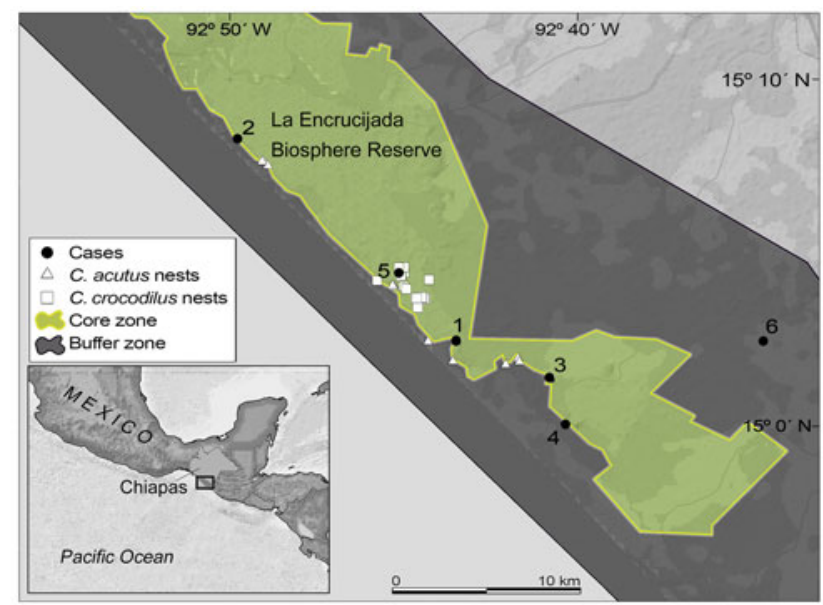

FIG. 1 La Encrucijada Biosphere Reserve, with the locations of the six negative interactions (cases) between people and crocodilians recorded during 2005-2018 (Table 2), five with American crocodiles Crocodylus acutus and one (Case 5) with a spectacled caiman Caiman crocodilus chiapasius, and nests recorded in 2014. For details of the six cases, see Table 2.

species has been recorded (Sigler \& Martínez-Ibarra, 1998; González-Desales et al., 2016a,b), and therefore we examined human-crocodilian interactions and abundance of crocodilians only in the core zone.

During October 2013-September 2014 we conducted unstructured interviews in the principal settlements on the margin of the El Hueyate estuary (Aztlán, Brisas del Hueyate and La Ceiba) with 22 people (five women and 17 men; 22-51 years old), who were either involved in incidents, or relatives of those involved. As the total population in these settlements is 543 , (CONABIO, 2014), we interviewed $4 \%$ of the total population. We focused on obtaining information about the date and location of any interactions, any actions taken against the crocodilians, activities that people were performing at the time of the incidents, and information from people that witnessed the events. From 2014 onwards we have made 2-3 visits per year to monitor reports of any additional negative interactions. We have knowledge of an incident that occurred in March 2017 but we have not yet been able to interview the family members of the affected person.

The abundance of C. acutus and C. crocodilus chiapasius was analysed using the Relative Abundance Index Rsp/ travelled distance, where Rsp is the number of records of each species and travelled distance is the total number of $\mathrm{km}$ travelled during monitoring (Sigler et al., 2011). We obtained relative abundance data of both crocodilians from literature (Martínez-Ibarra et al., 1997; Sigler \& Martínez-Ibarra, 1998; Peña, 2011) and our fieldwork in 2014. In El Hueyate estuary we conducted 24 surveys during March-October 2014 during the nesting season of C. acutus and C. crocodilus chiapasius. The surveys were performed from a $6 \mathrm{~m}$ boat with a $15 \mathrm{HP}$ outboard motor, using a 19
LED white light to search for the brightness of crocodilian eyes by projecting the light beam between the boat and the mangroves (Chabreck, 1966). When we located eye-shine we decreased speed and slowly headed towards the individual, to identify it (differentiation of the species was by the presence of bony crests and ossified inter-orbital bridge in the case of $C$. crocodilus, and the absence of these characteristics in C. acutus). The $28 \mathrm{~km}$ of the El Hueyate estuary monitored were the same stretch of the estuary surveyed in earlier studies (Martínez-Ibarra et al., 1997; Sigler \& Martínez-Ibarra, 1998; Peña, 2011).

\section{Results}

\section{Negative interactions with C. acutus in Mexico}

CrocBITE (2018) contains 121 records of negative interactions between people and C. acutus in Mexico during 15 August 1993-8 June 2018, and no reports of interactions with C. crocodilus chiapasius. Of the 121 records only 117 included geographical location. There was a significant negative relationship between the frequency of interactions and distance to the nearest nesting site $(r=-0.76$; $\mathrm{P}<0.05)$; i.e. there were more interactions closer to nesting sites. There was also a significant relationship between the number of negative interactions and presence records of $C$. acutus $(r=0.92 ; \mathrm{P}<0.05)$. There was no significant relationship between the frequency of negative interactions and the relative abundance of $C$. acutus $(r=-0.49, \mathrm{P}>0.05)$. With respect to the date of incidents, there were significantly more negative interactions during the nesting season than at other times $\left(\chi^{2}=22.87, \mathrm{df}=1, \mathrm{P}<0.001\right.$; Fig. 2$)$. Regarding the socio-economic characteristics of the 70 municipalities where there were negative interactions or presence records, the economic activity 'services' was the most common in municipalities where interactions (24 municipalities) and sightings occurred (34 municipalities), human population density was lower in municipalities with negative interactions (mean $0.9 \pm$ SD 1.1 inhabitants $/ \mathrm{km}^{2}$ ), and in municipalities with negative interactions $57.1 \%$ of the adult male population (15-64 years old) had a mean of $7.4 \pm$ SD 1.2 years of education.

\section{Human-crocodilian interactions in El Hueyate estuary}

We obtained data on the relative abundance of C. acutus in El Hueyate estuary for 1997, 1998, 2002 and 2008-2010, with 1.14-7.11 individuals per $\mathrm{km}$, and for C. crocodilus chiapasius for 2002 and 2008-2010, with $0-2.42$ individuals per $\mathrm{km}$ (Fig. 3a). The relative abundance index calculated for our fieldwork in 2014 was 1.5 C. acutus per $\mathrm{km}$ and $2.71 \mathrm{C}$. crocodilus chiapasius per $\mathrm{km}$.

We obtained information on six negative interactions between people and crocodilians in El Hueyate estuary 


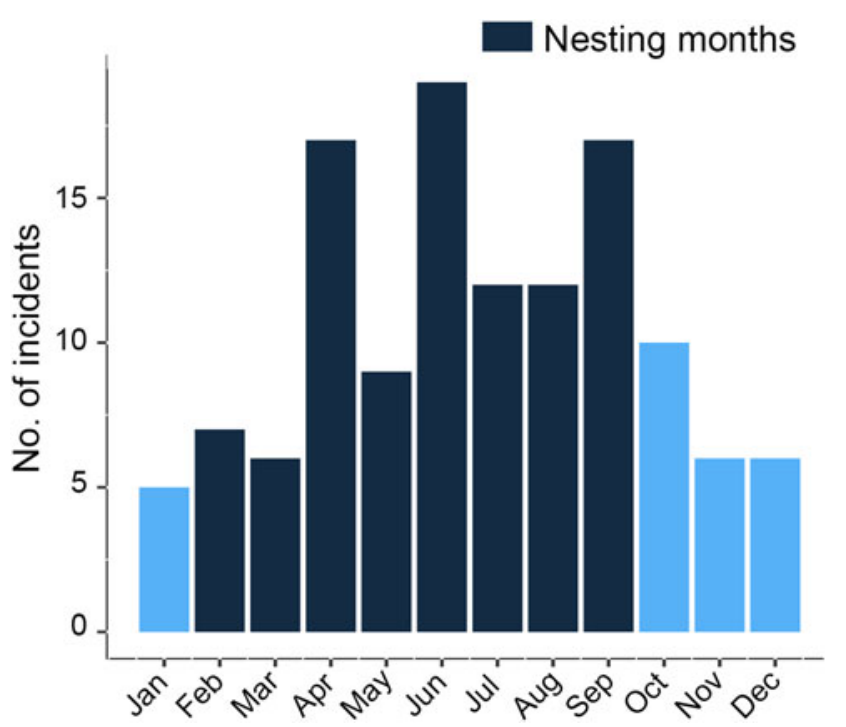

FIG. 2 Negative interactions by month involving C. acutus in Mexico, showing that the incidents are more frequent in nesting season.

during 2005-2014 (Fig. 3b). Two of the incidents were fatal, two resulted in major injury (limb loss or permanent motor impairment) and two resulted in minor injury. Five of the incidents involved C. acutus and one C. crocodilus chiapasius (Table 2).

According to the interviewees, incidents between crocodiles and domestic animals (mainly dogs) and livestock (cattle and pigs) are common in the area. Following negative interactions with crocodiles, 30 adult crocodiles were hunted by the inhabitants of the three settlements during 2011-2012. Five of the six negative interactions recorded occurred close to nesting sites (Table 2), where we observed 34 nests of $C$. acutus and 19 of C. crocodilus chiapasius in 2014 (Fig. 1; González-Desales et al., 2016a,b).

\section{Discussion}

As far as we are aware, this study is the first analysis of the potential causes of the negative interactions between people and C. acutus in Mexico, and the first standardized report of populations trends of C. crocodilus chiapasius and C. acutus in a coastal region of Chiapas. For Crocodylus porosus, in Australia and Sri Lanka, abundance and protection of the nest by females are the main factors that increase the probability of negative interactions with people (Caldicott et al., 2005; Amarasinghe et al., 2015). Our study suggests, however, that the abundance of $C$. acutus does not influence the frequency of incidents in Mexico.

The survey method used for the calculation of the relative abundance index is potentially subject to biases (GarcíaGrajales et al., 2007) and therefore the lower relative abundance we detected in La Encrucijada in 2014 cannot necessarily be attributed to the illegal killing of crocodiles.
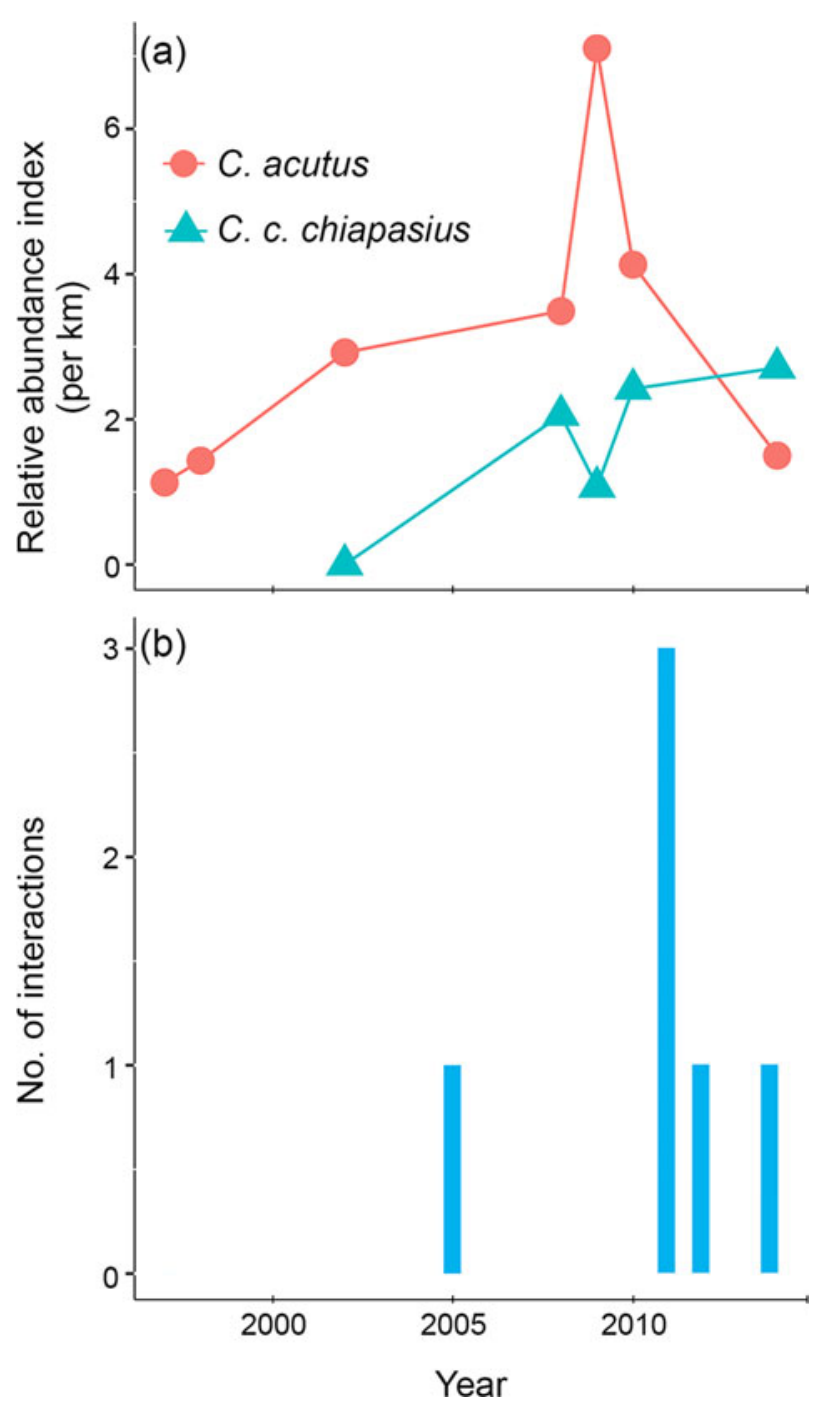

FIG. 3 (a) Relative abundance index (crocodilians observed per km, during 1997-2014) of C. acutus and C. crocodilus chiapasius, and (b) the number of negative human-crocodilian interactions per year (during 2005-2018), in El Hueyate estuary, La Encrucijada Biosphere Reserve, Mexico.

However, with illegal killings as high as 30 individual crocodiles per incident (according to the people we interviewed), such killings would be expected to affect abundance, especially if any of the crocodiles killed are reproductive females. A similar situation occurs in other regions of Mexico. Hernández-Hurtado et al. (2006) reported 11 negative incidents during 1993-2004 in the Western Pacific region, following which 155 crocodiles were hunted, injured or captured, of which 40 were hunted in Manzanilla, Jalisco. The illegal killing of crocodiles has been reported elsewhere after negative interactions, such as with C. porosus in Sri Lanka (Amarasinghe et al., 2015).

Following negative interactions between C. acutus and people in La Encrucijada, there was an apparent decrease in abundance of the species, to a level similar to that recorded when protection of the species began in this 
TABLE 2 Incidents of negative interactions with crocodilians during 2005-2018 in El Hueyate estuary and nearby areas. Case five was with a spectacled caiman Caiman crocodilus chiapasius and the other cases were with American crocodiles Crocodylus acutus.

\begin{tabular}{|c|c|c|c|c|c|c|c|c|c|}
\hline Case & Month \& year & $\begin{array}{l}\text { Age } \\
\text { (years) }\end{array}$ & Occupation & Activity & $\begin{array}{l}\text { Distance } \\
\text { incident-nest } \\
(\mathrm{km})\end{array}$ & $\begin{array}{l}\text { Actions following } \\
\text { incident }\end{array}$ & $\begin{array}{l}\text { Consequences of } \\
\text { incident for the } \\
\text { affected person }\end{array}$ & $\begin{array}{l}\text { Length of } \\
\text { crocodilian } \\
\text { (m) }\end{array}$ & $\begin{array}{l}\text { Actions against } \\
\text { crocodilians }\end{array}$ \\
\hline 1 & 2005 & 42 & Fisher & Unknown & 0.03 & $\begin{array}{l}\text { Search by local } \\
\text { authorities \& relatives } \\
\text { located clothing \& it } \\
\text { was concluded he was } \\
\text { killed by crocodiles }\end{array}$ & Fatal & Unknown & None \\
\hline 2 & April 2011 & 21 & Student, fisher & $\begin{array}{l}\text { Swimming in } \\
\text { the estuary }\end{array}$ & 1.72 & $\begin{array}{l}\text { Medical \& psychological } \\
\text { attention }\end{array}$ & $\begin{array}{l}\text { Non-fatal, loss of } \\
\text { right arm }\end{array}$ & 3.7 & $\begin{array}{l}\text { Killing crocodiles until } \\
\text { missing arm located }\end{array}$ \\
\hline 3 & February 2011 & 35 & Fisher & $\begin{array}{l}\text { Preparing a bird } \\
\text { on the estuary } \\
\text { bank }\end{array}$ & 0.01 & Medical attention & $\begin{array}{l}\text { Non-fatal, scars on } \\
\text { abdomen }\end{array}$ & 2.5 & None \\
\hline 4 & 2011 & 32 & Fisher & $\begin{array}{l}\text { Fishing at the } \\
\text { estuary shore }\end{array}$ & 1.93 & Medical attention & $\begin{array}{l}\text { Non-fatal, lesions on } \\
\text { the foot } \& \text { difficulty } \\
\text { with walking }\end{array}$ & 2.5 & $\begin{array}{l}\text { Killing crocodiles } \\
\geq 2.5 \mathrm{~m} \text { long }\end{array}$ \\
\hline 5 & May 2012 & 44 & Fisher & $\begin{array}{l}\text { Cast netting in } \\
\text { swampy areas }\end{array}$ & 0.12 & Medical attention & $\begin{array}{l}\text { Non-fatal, scars on } \\
\text { right foot \& left hand }\end{array}$ & 1.5 & None \\
\hline 6 & June 2014 & 46 & Unknown & $\begin{array}{l}\text { Swimming } \\
\text { under the } \\
\text { influence of } \\
\text { alcohol }\end{array}$ & 12.61 & $\begin{array}{l}\text { Human remains recovered } \\
\text { by municipality \& } \\
\text { federal authorities }\end{array}$ & Fatal & Unknown & $\begin{array}{l}\text { Killing of crocodiles by } \\
\text { local people \& crocodile } \\
\text { translocation by local } \\
\text { authorities }\end{array}$ \\
\hline
\end{tabular}


area. Management strategies are now required for this crocodile population, as employed in 1998 and 1999 when eggs were recovered from nesting areas within the estuary, with 123 offspring reared from 126 incubated eggs and then released in the Reserve (Sigler et al., 2000). In other regions of Mexico, habitat protection, nest and clutch care, and long-term monitoring have helped the recovery of C. acutus populations (García et al., 2010).

Since 2011, following the incidents with crocodiles, people living along El Hueyate estuary no longer engage in fish harpooning for fear of being attacked; they also destroy crocodile eggs (Sigler \& Martínez-Ibarra, 1998; Sigler et al., 2000; González-Desales et al., 2016a) and no longer swim or bathe in the estuary. Negative human-crocodilian interactions affect both parties (Table 2; Pooley, 2015). People may suffer fatal incidents, temporary or permanent physical and/or psychological damages, economic expenses and loss of domestic animals. The decline of a crocodile population can affect the local economy directly, and negatively, as a result of an increase in species of mammals, birds and arthropods considered problematic for agriculture (Cott, 1961; Fittkau, 1973), and short-term ecological imbalance (Nifong, 2018).

It is therefore important to collect data systematically, to understand the dynamics of crocodile populations and to document their interactions with people and, subsequently, to recommend actions that facilitate coexistence (Pooley, 2015). Ecotourism and sustainable harvest of crocodilian populations are potential management strategies (Fukuda et al., 2014). To conserve crocodiles, it is vital to involve all stakeholders, including government agencies, non-governmental organizations, business and tourism sectors, the media, and the public, both rural and urban.

The majority $(78.5 \%)$ of incidents occurred during February-September, the nesting season of C. acutus, which is similar to Crocodylus palustris in India, where $71.8 \%$ of incidents were reported during the breeding season (Vyas \& Stevenson, 2017). The main local economic activity is fishing within the estuary, close to nesting sites (HernándezHurtado et al., 2006; Das \& Jana, 2017). Although the inhabitants in the study area suggested that the increase of crocodiles in the estuary is the main cause of negative interactions, our findings suggest otherwise: negative interactions also occurred when crocodile abundance was low, such as in 2014 (Fig. 3). Another important aspect to consider is a crocodile's length (Fukuda et al., 2015): the average size of the crocodiles responsible for negative interactions in Mexico was $2.8 \mathrm{~m}$ (range $0.5-4.0 \mathrm{~m}$ ), and in 36 cases the crocodiles were reported to be $>2 \mathrm{~m}$ in length (CrocBITE, 2018). The crocodiles involved in the negative interactions in El Hueyate estuary measured 1.5$3.7 \mathrm{~m}$ in length (Table 2), and the dates of the incidents recorded corresponded to the months of courtship, nesting or care of neonates. In other species of crocodilians it has been documented that anthropogenic activities such as swimming, fishing, washing, walking near sources of water, sailing, catching crocodilians, falling into the water, bathing cattle, collecting water or crossing a body of water, are the main circumstances in which negative interactions occur between people and crocodiles (Caldicott et al., 2005; Langley, 2005; Jayson et al., 2006; Dunham et al., 2010; Brien et al., 2017).

Our findings indicate a relationship of negative humancrocodilian interactions with anthropogenic activities and the crocodile reproductive season (nesting and care of hatchlings), and potentially to some socio-economic characteristics of the municipalities where negative incidents occur. This is also the pattern on the Mexican Pacific coast. Abundance of crocodilians does not appear to determine the frequency of negative interactions, but the probability of negative interactions may increase in locations with more crocodile sightings. This should be considered in the safeguarding of tourists and the local population: monitoring of wild populations of $C$. acutus would help to establish whether there are more negative incidents at sites with greater numbers of crocodiles. Consideration of the socio-economic characterization of municipalities, and locating nesting zones, are the first steps required to identify risk sites and to implement prevention strategies: for example, signage at risk sites such as nesting areas and training of response groups for incidents with crocodiles.

Negative interactions between people and crocodiles are increasing in Mexico (García-Grajales \& Buenrostro-Silva, 2019), and the study of this phenomenon is necessary to support public policies, possibly including the translocation or removal of troublesome individual crocodiles. Conservation strategies need to consider the ecological, socio-economic and cultural aspects of these interactions, to avoid the illegal killing of crocodiles (Carter et al., 2017). Public education about crocodiles needs to be improved, to inform people about high risk situations and how to avoid them, but it is also imperative to convey why crocodiles need to be conserved (Pooley, 2015; Cureg et al., 2016; Sideleau et al., 2017). Conveying this message to the diverse range of stakeholders could include various strategies such as the use of brochures, pamphlets, signage, media coverage, posters, public presentations and tourist guides (Amarasinghe et al., 2015).

Finally, we make the following recommendations: (1) monitoring recreational activities near the sites and during the nesting season (depending on the site, FebruarySeptember) by tourism service providers and institutions responsible for crocodile monitoring and administration of natural areas, (2) dissemination of information on the possible risk of incidents, (3) protection of eggs in incubation pens, and (4) encouraging strategies to meet the social and economic needs of the local human population. We have implemented some of these strategies in El Hueyate estuary, and so far there have not been any reports of 
further incidents. Signs are erected during the nesting season, and 58 nests were protected during $2013-2016$ by local people (García-Grajales et al., 2019). We are continuing these activities.

Acknowledgments We thank Consejo Nacional de Ciencia y Tecnología and the Universidad Autónoma del Estado de México (Scholarship 360827, Project 3841/2014/CIA) for funding; sponsors of the Student Research Assistance Scheme for financing the fieldwork through the IUCN Crocodile Specialist Group (Project 14/3); B. Sideleau for maintenance of CrocBITE; the people of La Encrucijada Biosphere Reserve for sharing details of their problems with crocodiles; the Island Conception ecotourism project for providing facilities during fieldwork; and Xareni Pacheco for help with the text.

Author contributions Development of concept and methods: GAG-D, MMZ-G, OM-V; fieldwork: GAG-D, LS; writing: all authors; organization of crocodile monitoring and interviews: MMZ-G, OM-V; financial management: PC, MMZ-G, OM-V; data analysis: GAG-D, AB-S; translation: LS.

\section{Conflicts of Interest None.}

Ethical Standards The Universidad Autónoma del Estado de México approved this research under its code of ethics, no crocodilians were captured in the course of the fieldwork, people interviewed allowed us to make use of the information obtained, and the research otherwise abided by the Oryx guidelines on ethical standards.

\section{References}

Aguilar-Galindo, A. (2005) Evaluación del estado de conservación del caiman Crocodilus fuscus (Mertens, 1943) durante el año 20032004, en el sistema lagunar de Chantuto, Reserva de la Biosfera La Encrucijada, Chiapas, México. BSc thesis. Universidad Autónoma Metropolitana, Xochimilco, Mexico.

Amarasinghe, A.A., Madawala, M.B., Karunarathna, D.M.S., Manolis, C., De Silva, A. \& Sommerlad, R. (2015) Humancrocodile conflict and conservation implications of saltwater crocodiles Crocodilus porosus (Reptilia: Crocodylia: Crocodylidae) in Sri Lanka. Journal of Threatened Taxa, 7, 7111-7130.

Aust, P., Boyle, B., Fergusson, R. \& Coulson, T. (2009) The impact of Nile crocodiles on rural livelihoods in northeastern Namibia. South African Wildlife Research, 39, 57-69.

Balaguera-Reina, S.A. \& Velasco, A (2019) Caiman crocodilus. In The IUCN Red List of Threatened Species 2019: e.T46584A3009688. dx.doi.org/10.2305/IUCN.UK.1996.RLTS. T46584A11062106.en [accessed 14 January 2020].

Brandon-Pliego, J.D. (2007) Estudio poblacional de Crocodylus acutus (Cuvier, 1807) (Reptilia: Crocodylia) en Jamiltepec, Oaxaca. Ciencia y Mar, 11, 29-37.

Brien, M.L., Gienger, C.M., Browne, C.A., Read, M.A., Joyce, M.J. \& Sullivan, S. (2017) Patterns of human-crocodile conflict in Queensland: a review of historical estuarine crocodile (Crocodylus porosus) management. Wildlife Research, 44, 281-290.

Caldicott, D.G., Crozer, E., Manolis, C., Webb, G. \& Briton, A. (2005) Crocodile attack in Australia: an analysis an analysis of its incidents and review of the pathology and management of crocodilian attacks in general. Wilderness \& Environmental Medicine, 16, 143-159.

Carter, N.H., López-Bao, J.V., Bruskotter, J.T., Gore, M., Chapron, G., Johnson, A. et al. (2017) A conceptual framework for understanding illegal killing of large carnivores. Ambio, 46, 251-264.

Casas-Andreu, G. (2003) Ecología de la anidación de Crocodylus acutus (Reptilia: Crocodylidae) en la desembocadura del río Cuixmala, Jalisco, México. Acta Zoológica Mexicana, 89, 111-128.

Castillo, F.A. (1996) American crocodile in the Central Pacific Region. Crocodile Specialist Group Newsletter, 15, 17.

Cedeño-Vázquez, J.R., Platt, S.G. \& Thorbjarnarson, J. (2012) Crocodylus moreletii. In The IUCN Red List of Threatened Species 2012: e.T5663A3045579. dx.doi.org/10.2305/IUCN.UK.2012.RLTS. T5663A3045579.en [accessed 22 April 2017].

Cedillo-Leal, C., García-Grajales, J., Martínez-González, J.C., Briones-Encinia, F. \& Cienfuegos-Rivas, E. (2013) Aspectos ecológicos de la anidación de Crocodylus acutus (Reptilia: Crocodylidae) en dos localidades de la costa de Oaxaca, México. Acta Zoológica Mexicana, 29, 164-177.

Chabreck, R.H. (1966) Methods of determining the size and composition of alligator population in Louisiana. Proceedings of the Annual Conference of the Southeastern Association of Game and Fish Commissioners, 20, 105-112.

Charruau, P., Cendeño-Vázquez, J.R. \& Calmé, S. (2005) Status and conservation of the American crocodile (Crocodylus acutus) in Banco Chinchorro biosphere reserve, Quintana Roo, Mexico. Herpetological Review, 36, 390-395.

Charruau, P., Thorbjarnarson, J.B. \& Hénaut, Y. (2010) Tropical cyclones and reproductive ecology of Crocodylus acutus Cuvier, 1807 (Reptilia: Crocodylia: Crocodylidae) on a Caribbean atoll in Mexico. Journal of Natural History, 44, 741-761.

Charruau, P., Méndez-de la Cruz, F.R. \& González-Cortés, H. (2011) Preliminary results on nesting ecology of Crocodylus acutus on Cozumel Island, Mexico. Crocodile Specialist Group Newsletter, 30, 29-32.

Charruau, P., Hernández-Marcial, F. \& Méndez-de la Cruz, F.R. (2017) Reproductive ecology of the American crocodile in northern Quintana Roo, Mexico. Quehacer Científico en Chiapas, $12,18-23$.

CONABIO (Comisión Nacional para el Conocimiento y Uso DE LA Biodiversidad) (2014) Caracteristicas económicas por localidad, 2010. Catálogo de metadatos geográficos. Comisión Nacional para el Conocimiento y Uso de la Biodiversidad, México. conabio.gob.mx/informacion/gis [accessed 14 November 2018].

Сотт, H.B. (1961) Scientific results of an enquiry into the ecology and economic status of the Nile crocodile (Crocodylus niloticus) in Uganda and Northern Rhodesia. Transactions of the Zoological Society of London, 29, 211-358.

CrocBITE (2018) The Worldwide Crocodilian Attack Database. crocodile-attack.info [accessed 3 June 2018].

Cupul-Magaña, F., Rubio-Delgado, F.A., Reyes-Juárez, A. \& Hernández-Hurtado, H. (2002) Sondeo poblacional de Crocodylus acutus (Cuvier, 1807) en el Estero Boca Negra, Jalisco. Ciencia y Mar, 6, 45-50.

Cupul-Magaña, F., Niz-Villaseñor, A., Reyes-Juárez, A. \& Rubio-Delgado, A. (2004) Historia Natural del cocodrilo americano (Crocodylus acutus) en el estero Boca Negra, Jalisco, México: anidación y crecimiento de neonatos. Ciencia y Mar, $8,31-42$.

Cureg, M.C., Bagunu, A.M., van Weerd, M., Balbas, M.G., Soler, D. \& van Der Ploeg J. (2016) A longitudinal evaluation of the Communication, Education and Public Awareness (CEPA) campaign for the Philippine crocodile Crocodylus mondorensis in northern Luzon, Philippines. International Zoo Yearbook, $50,68-83$. 
Das, C. \& JANA, R. (2017) Human-crocodile conflict in the Indian Sundarban: an analysis of spatio-temporal incidences in relation to people's livelihood. Oryx, 52, 661-668.

Dunham, K.M., Ghiurghi, A., Cumbi, R. \& Urbano, F. (2010) Human-wildlife conflict in Mozambique, a national perspective, with emphasis on wildlife attacks on humans. Oryx, 44, 185-193.

Espinosa-Reyes, G. \& García-Grajales, J. (2001) Densidad Poblacional y Estructura por Tallas de la Población del Cocodrilo de Río (Crocodylus acutus Cuvier, 1807) en el Estero de la Ventanilla, Oaxaca. Unpublished report. COMACROM, Culiacán, Sinaloa, Mexico.

Fittkau, E.J. (1973) Crocodiles and the nutrient metabolism of Amazonian waters. Amazoniana, 4, 103-133.

Fukuda, Y., Manolis, C. \& Appel, K. (2014) Management of human-crocodile conflict in the Northern territory, Australia: review of crocodile attacks and removal of problem crocodiles. The Journal of Wildlife Management, 78, 1239-1249.

Fukuda, Y., Manolis, C., SAalfeld, K. \& ZuUR, A. (2015) Dead or alive? Factors affecting the survival of victims during attacks by saltwater crocodiles (Crocodylus porosus) in Australia. PLOS ONE, 10, e 0126778.

García, A., Valtierra-Azotla, M., Cuarón, A. \& Ceballos, G. (2010) Tendencias poblacionales de Crocodylus acutus en condiciones de protección en la Reserva de la Biosfera Chamela-Cuixmala, Jalisco, México. Revista Latinoamericana de Conservación, 1, 52-62.

García-Grajales, J. (2013) El conflicto hombre-cocodrilo en México: causas e implicaciones. Interciencia, 38, 881-884.

García-Grajales, J. \& Buenrostro-Silva, A. (2014) Abundancia y estructura poblacional de Crocodylus acutus (Reptilia: Crocodylidae) en la Laguna Palmasola, Oaxaca, México. Revista de Biología Tropical, 62, 165-172.

García-Grajales, J. \& Buenrostro Silva, A. (2018) Crocodile attacks in Oaxaca, Mexico: an update of its incidences and consequences for management and conservation.

Acta Universitaria, 28, 1-8.

García-Grajales, J. \& Buenrostro-Silva, A. (2019) Assessment of human-crocodile conflict in Mexico: patterns, trends and hotspots areas. Marine and Freshwater Research, 70, 708-720.

García-Grajales, J., Buenrostro-Silva, A. \& EscobedoGalván, A. (2007) Análisis de los métodos usados para estimar la abundancia de las poblaciones silvestres de cocodrilianos (Crocodylia) en México. Ciencia y Mar, 11, 23-32.

García-Grajales, J., González-Desales, G.A. \& López-Luna, M.A. (2019) Cocodrilos de México: Perspectivas de Manejo y Conservación. In Situación Actual de los Grandes Depredadores (eds O. Monroy-Vilchis, V. Urios \& M.M. Zarco-González). pp. 213-215. Colofón Ediciones Académicas, Mexico City, Mexico.

GBif (Global Biodiversity Information Facility) (2017) Crocodylus acutus (Cuvier, 1807) in GBIF Secretariat. GBIF Backbone Taxonomy. gbif.org [accessed 18 June 2018].

GonzÁlez, E.M. (2013) Ecología poblacional del cocodrilo de río (Crocodylus acutus, Cuvier 1807) en la Presa El Cajón, Nayarit, México. BSc thesis. Centro Universitario de Ciencias Biológicas y Agropecuarias, Universidad de Guadalajara, Guadalajara, Mexico.

González-Desales, G.A., Monroy-Vilchis, O., ZarcoGonzÁlez, M.M. \& Charruau, P. (2016a) Nesting ecology of the American crocodile in La Encrucijada biosphere reserve, Mexico. Amphibia-Reptilia, 37, 261-271.

González-Desales, G.A., Monroy-Vilchis, O., Charruau, P. \& Zarco-González, M.M. (2016b) Aspectos ecológicos de la anidación de Caiman crocodilus chiapasius (Bocourt, 1976) en la reserva de la biosfera La Encrucijada, México. Animal Biodiversity and Conservation, 39, 155-160.
Hernández-Hurtado, H., García-de Quevedo, M. \& Hernández-Hurtado, P.S. (2006) Los cocodrilos de la costa Pacífico occidental (Michoacán, Colima y Jalisco) de México. In Los Recursos Pesqueros y Acuícolas de Jalisco, Colima y Michoacán (eds M.C. Jiménez \& E. Espino), pp. 375-389. Secretaría de Agricultura, Ganadería, Desarrollo Rural, Pesca y Alimentación, Instituto Nacional de Pesca, Mexico City, Mexico.

Hernández-Hurtado, H., Romero-Villaruel, J.J. \& Hernández-Hurtado, P.S. (2011) Ecología poblacional de Crocodylus acutus en los sistemas estuarinos de San Blas, Nayarit, México. Revista Mexicana de Biodiversidad, 82, 887-895.

Huerta, S.M. (2005) Dinámica poblacional del caimán (Crocodylus acutus, Cuvier 1807, Crocodylidae) en Jalisco, México. MSc thesis. Centro Universitario de Ciencias Biológicas y Agropecuarias, Universidad de Guadalajara, Guadalajara, Mexico.

INE-SEMARNAP (Instituto NACIONAL DE Ecología-Secretaría de Medio Ambiente, Recursos Naturales y Pesca) (1999) Programa de Manejo Reserva de la Biosfera La Encrucijada, México. Instituto Nacional de Ecología, Secretaria de Medio Ambiente, Recursos Naturales y Pesca, Mexico City, Mexico.

ineGi (Instituto Nacional de Estadística y Geografía) (2019) Catálogo Nacional de Indicadores. snieg.mx/cni/indicadores. aspx?idOrden $=1.1$ [accessed 8 January 2019].

Jayson, E.A., Sivaperuman, C. \& Padmanbhan, P. (2006) Review of the reintroduction program of the mugger crocodile Crocodylus palustris in the Neyyar reservoir, India. Herpetological Journal, $16,69-76$.

LANGLEY, R.L. (2005) Alligator attacks on humans in the United States. Wilderness Environmental Medicine, 16, 119-124.

León-Ojeda, F.J., Bagazuma-Mendoza, P. \& ArredondoRamos, P. (1997) Evaluación Poblacional y Algunos Aspectos Ecológicos de Crocodylus acutus en la Laguna de Chiricahueto. Unpublished report. 4th Meeting of the Crocodile Specialist Group of Latin America and the Caribbean. Villahermosa, Tabasco, Mexico.

Martínez-Ibarra, J.A., Naranjo, E. \& Nelson, K.C. (1997) Las poblaciones de cocodrilos (Crocodylus acutus) y caimanes (Caiman crocodilus) en una zona pesquera de la reserva de la biosfera "La Encrucijada”, Chiapas, México. Vida Silvestre Neotropical, 6, 21-28. Navarro-Serment, C.J. (2001) Uso de Hábitat y Conservación de Crocodylus acutus en el Estero El Verde, Sinaloa. Unpublished Report. COMACROM, Culiacán, Sinaloa, Mexico.

Nifong, J. (2018) Ecological value of crocodilians. In Crocodilian Capacity Building Manual. Crocodile Specialist Group. iucncsg.org/ pages/Crocodilian-Capacity-Building-Manual-.html [accessed 12 November 2018].

PeñA, E.J. (2011) Abundancia relativa de Crocodylus acutus $y$ Caiman crocodilus en la Reserva de la Biosfera La Encrucijada en Chiapas, México. BSc thesis. Facultad de Medicina Veterinaria y Zootecnia, Universidad Autónoma de Chiapas, Chiapas, Mexico.

Ponce-Campos, P., Thorbjarnarson, J.B. \& Velasco, A. (2012) Crocodylus acutus. In The IUCN Red List of Threatened Species 2012: e.T5659A3043244. dx.doi.org/10.2305/IUCN.UK.2012.RLTS.

T5659A3043244.en [accessed 22 April 2017].

Pooley, S. (2015) Using predator attack data to save lives, human and crocodilian. Oryx, 49, 581-583.

Pooley, A.C., Hines, T.C. \& Shield, J. (1989) Attacks on humans. In Crocodiles and Alligators (eds C.A. Ross \& S. Garnett), pp. 172-1879. Facts on File, New York, USA.

Semarnat (Secretaría de Medio Ambiente y Recursos Naturales) (2010) Norma Oficial Mexicana NOM-059-SEMARNAT-2010. Diario Oficial de la Federación, Mexico City, Mexico. 
Sideleau, B. (2015) Recent reports of fatal attacks on humans by crocodiles in Mexico. Crocodile Specialist Group Newsletter, $34,21-22$.

Sideleau, B.M., Edyvane, K.S. \& Britton, A.R.C. (2017) An analysis of recent saltwater crocodile (Crocodylus porosus) attacks in Timor-Leste and consequences for management and conservation. Marine and Freshwater Research, 68, 801-809.

SigLER, L. (1996) Situación del caimán en Chiapas. In Crocodiles. Proceedings of the 13th working meeting of the Crocodile Specialist Group, Santa Fe, Argentina.

Sigler, L. (2010) La Historia Natural del cocodrilo americano Crocodylus acutus en el Parque Nacional Cañón del Sumidero, Chiapas, México. Revista Latinoamericana de Conservación, $1,73-82$.

Sigler, L. \& Martínez-Ibarra, J.A. (1998) Diagnóstico del Estado Actual de las Poblaciones de Cocodrilianos Caiman crocodilus $y$ Crocodylus acutus en la Reserva de la Biosfera La Encrucijada, Chiapas. Informe Final del Proyecto RNMA-051-96. Unpublished report. Consejo Nacional de Ciencia y Tecnología, Instituto de Historia Natural, Mexico City, Mexico.

Sigler, L., López, M.P., Muñiz, C.M. \& González-Blanco, S.B. (2000) Management of wild Crocodylus acutus clutches under natural forced incubation at "La Encrucijada" biosphere reserve, Chiapas, Mexico. In Crocodiles. Proceedings of the 15th working meeting of the Crocodile Specialist Group, Varadero, Cuba.

Sigler, L., Cedeño-VÁzquez, J.R. \& Cupul-Magaña, F. (2011) Método de detección visual nocturna (DVN). In Programa de Monitoreo del Cocodrilo de Pantano (Crocodylus moreletii) México-Belice-Guatemala (eds O. Sánchez-Herrera, G. López-Segurajáuregui, A. García-Naranjo Ortiz de la Huerta \& H. Benítez-Díaz), pp. 105-127. Comisión Nacional para el Conocimiento y Uso de la Biodiversidad, Mexico City, Mexico. Sturges, H. (1926) The choice of a class-interval. Journal of the American Statistical Association, 21, 65-66.

Tello, L.A. (2016) Estudio Poblacional de Cocodrilo de Río (Crocodylus acutus, Cuvier 1807) en el Estero Majahuas y la Laguna de San Juan, Tomatlán, Jalisco. Congreso Mesoamericano de Investigación, 3, 95-96.

Uetz, P., Freed, P. \& Hošen, J. (2016) The Reptile Database. reptile-database.org [accessed 3 April 2017].

Valtierra-Azotla, A.M. (2007) Ecología poblacional y reproductiva del cocodrilo americano (Crocodylus acutus) en la Reserva de la Biosfera Chamela-Cuixmala. MSc thesis. Universidad Michoacana de San Nicolás de Hidalgo, Morelia, Michoacán, Mexico.

Vyas, R. \& Stevenson C. (2017) Review and analysis of human and Mugger crocodile conflict in Gujarat, India from 1960 to 2013.

Journal of Threatened Taxa, 9, 11016-11024. 